\title{
Pendampingan terkait Konsep diri, Kepemimpinan \& Kewirausahaan bagi Pelajar SMA/SMK/MA Penerima Beasiswa BAZNAS Daerah Istimewa Yogyakarta Tahun Anggaran 2019
}

\author{
Andriyastuti Suratman \\ Program Studi S1 Manajemen, Fakultas Ekonomi \\ Universitas Islam Indonesia \\ Majang Palupi \\ Program Studi S1 Manajemen, Fakultas Ekonomi \\ Universitas Islam Indonesia
}

\begin{abstract}
This activity is initiated by a community service team with BAZNAS Special Region of Yogyakarta (Daerah Istimewa Yogyakarta) as a partner. This activity was funded by Directorate of Research and Community Service (Direktorat Penelitian dan Pengabdian Masyarakat) of Universitas Islam Indonesia. This team did synergy with BAZNAS DIY that has scholarships program for high school - SMA/SMK/Madrasah Aliyah students totaling 105 participants in the entire Yogyakarta Province. Mentoring was delivered in three stages or meetings; about Islamic self-concept and SWOT analysis with classical method, leadership and teamwork with outbond method and entrepreneurship with classical and student center learning by forum group discussion. This activity was also preceded by a forum discussion with BAZNAS DIY leaders and ended with a report.
\end{abstract}

Keywords: community service, self-concept, SWOT analysis, entreprenurship, BAZNAS DIY, $\& 2019$.

\section{PENDAHULUAN}

Sumber daya manusia merupakan frase yang terdiri dari dua hal; resource dan human, bermakna segala daya yang dimiliki oleh manusia. Segala daya baik secara fisik dan psikis inilah yang menghadirkan "will do" dan "can do" dalam segala aktivitasnya. Proses pengembangan KSA (knowledge, skill dan ability) yang melekat pada manusia tidak hanya dimulai dari proses rekrutmen dan seleksi dalam perusahaan. Lebih luas dan lebih panjang jalannya ditempuh sejak masa sekolah anak (baik formal dan informal) untuk membentuk karakter manusia jangka panjang, melalui pembiasaan, pengkondisian dan edukasi terstruktur mengarahkan manusia menuju kehidupan yang lebih baik (atau pun sebaliknya) sesuai dengan firman Allah : 
"Sesungguhnya Allah tidak mengubah keadaan sesuatu kaum sehingga mereka mengubah keadaan yang ada pada diri mereka sendiri" (QS. Ar ra'du: 11). Maka dari itu melalui Al-Qur'an pula Islam mendorong manusia secara individu untuk memperhatikan dirinya sendiri, keistimewaannya dari makhluk lain dan proses penciptaan dirinya sebagai bentuk intropeksi tentang siapa diri manusia. "Dan di bumi itu terdapat tanda-tanda (kekuasaan Allah) bagi orang - orang yang yakin, (20) dan (juga) pada dirimu sendiri. Maka apakah kamu tiada memperhatikan (21)?” (QS. Adz-Dzariyat:20-21).

Pengembangan sumber daya manusia dapat diawali dengan konsep diri yang secara konseptual, teroganisir dan secara konsisten menghadirkan persepsi, sifat dan subyektivitas diri dengan berbagai aspek lingkungan yang membentuk diri seseorang (Mokoginta, 2001:536). Brooks mendefinisikan konsep diri adalah pandangan dan perasaan manusia akan dirinya secara psikologis, sosial dan fisik (dalam Rakhmat, 2007). Merujuk pada Rakhmat (2007) konsep diri merupakan sesuatu yang dipikirkan dan dirasakan oleh seseorang yang memiliki dua komponen; 1) kognitif, pengetahuan individu tentang diri nya sendiri dan 2) afektif, merupakan penilaian individu terhadap dirinya yang akan membentuk bagaimana penerimaan akan diri dan harga diri individu yang bersangkutan. Sedangkan Suryabrata (2006: 378) menyatakan bahwa konsep diri mempunyai empat aspek, yaitu bagaimana orang mengamati dirinya sendiri, bagaimana orang berpikir tentang dirinya sendiri, bagaimana orang menilai dirinya sendiri, bagaimana berusaha dengan berbagai cara untuk menyampaikan dan mempertahankan diri. Pengenalan konsep diri tidaklah secara instan dapat dikenali. Beberapa tahapan banyak dialami seseorang melalui proses belajar. Dengan proses belajar, seseorang dapat memperoleh pengalaman baru dalam bentuk perubahan perilaku yang relatif menetap, sebagai akibat adanya proses dalam bentuk interaksi belajar terhadap suatu objek (pengetahuan), atau melalui suatu penguatan (reinforcement) dalam bentuk pengalaman terhadap suatu objek yang ada dalam lingkungan belajar Uno (2011: 15). Kemampuan remaja dalam menyesuaikan diri dipengaruhi oleh banyak faktor, antara lain dipengaruhi oleh konsep diri dan kecerdasan emosi (Mutammimah, 2014). Apabila penyesuaian diri dikaitkan dengan proses belajar yang berkesinambungan, akan membantu seseorang (dalam hal ini siswa) untuk mampu menyesuaikan diri dalam lingkungan sekolah mulai dari pendidikan non formal atau daycare, taman kanakkanak, sekolah dasar dan seterusnya sehingga hal ini semakin penting dan 
krusial manakala anak sudah menginjak remaja. Remaja yang mampu melakukan penyesuaian diri, kehidupannya baik di sekolah, pekerjaannya, maupun masyarakat akan lebih sukses dibandingkan dengan yang tidak mampu melakukan penyesuaian diri.

Kegiatan pengabdian ini didanai oleh Direktorat Penelitian dan Pengabdian Masyarakat Universitas Islam Indonesia (DPPM UII) melalui hibah pengabdian masyarakat tahun 2019. Dalam kegiatan ini pengabdi dan tim yang terdiri dari dosen dan beberapa mahasiswa bekerja sama dengan pihak Badan Amil Zakat Nasional (BAZNAS) Daerah Istimewa (DI) Yogyakarta. BAZNAS DI. Yogyakarta memiliki beberapa program unggulan. Yaitu; Jogja Taqwa, Jogja Sejahtera, Jogja Peduli, Jogja Cerdas dan Jogja Sehat. Khususnya untuk Jogja Cerdas, BAZNAS Yogyakarta berupaya mendukung peningkatan kualitas dan kuantitas peserta didik kurang mampu tingkat TK/RA s.d. SMA/MA/SMK dengan program beasiswa anak asuh, rumah cerdas.

Tanggal 10 Februari 2019 telah terlaksana proses seleksi baca Al-Qur'an yang telah diikuti oleh para siswa dengan latar belakang anak yatim yang merupakan siswa SMA (46 siswa), SMK (137 siswa) dan MA (68 siswa) dengan total 251 siswa peserta calon penerima manfaat BEASISWA se DIY. Dari proses seleksi tersebut didapatkan 105 anak yatim siswa SMA/MA/SMK penerima beasiswa sebanyak masing-masing 3,6 juta rupiah dalam kurun satu tahun. Mayoritas penerima beasiswa berasal dari Kabupaten Kulonprogo dan Gunung Kidul. Selama kurun waktu satu tahun ke depan, mitra BAZNAS DIY memiliki rencana untuk melakukan pendampingan atau pembinaan para siswa penerima beasiswa tersebut dengan agenda yang bersifat penguatan karakter diri yang Islami dan berupaya untuk lebih meningkatkan motivasi siswasiswa tersebut untuk terus berprestasi. Meskipun pendampingan lebih berfokus pada konsep diri dan leadership, dalam praktiknya juga dikaitkan dengan masalah teamwork yang merupakan bagian dari kepemimpinan untuk melakukan berbagai aktivitas sebagai upaya mencapai sesuatu. Poin yang dikedepankan bahwa dalam berIslampun tidak dapat lepas dari adanya bermuamalah (dalam hal ini teamwork), sehingga harapan ke depan tidak hanya menghasilkan generasi penerus untuk menjadi pemimpin namun juga mampu bekerja sama dalam segala hal sepanjang itu memang diperbolehkan dalam Islam. Selain itu pada satu pertemuan terakhir disampaikan materi kewirausahaan sebagai materi suplemen. Di mana dengan perkembangan dunia yang sangat cepat dan penuh ketidakpastian, berwirausaha menjadi salah satu pilihan. Materi 
kewirausahaan ini disampaikan tidak melulu masalah menghasilkan atau menjual sesuatu, namun menjadi satu motivasi seseorang untuk senantiasa memiliki daya pejuang atau wira secara mandiri atau swasta. Menurut Wirasasmita dalam Suryana (2013:35), yang menjadi alasan atau motivasi seseorang untuk berwirausaha adalah: 1) alasan keuangan, 2) alasan sosial, 3) alasan pelayanan, dan 4) alasan pemenuhan diri. Sehingga dengan satu atau beberapa alasan yang tersebut tadi akan memperkuat para pelajar untuk senantiasa berjuang baik sebagai pelajar, anak bagi orang tuanya dan kelak menjadi masyarakat pada umumnya.

\section{RUMUSAN MASALAH}

Masalah yang coba untuk diantisipasi melalui kegiatan pengabdian masyarakat ini diarahkan pada pengembangan psikis pada siswa SMA/SMK/MA penerima beasiswa BAZNAS DI. Yogyakarta. Yaitu; pentingnya pembinaan siswa tentang konsep diri, mengenal pentingnya kepemimpinan dan bekerja sama dengan orang lain. Tidak hanya lebih mengedepankan (berorientasi) pada hasil nilai di raport. Juga memberikan wacana pada diri siswa penerima beasiswa BAZNAS Yogyakarta untuk menjadi entrepreneur atau wirausahawan agar memiliki sikap mandiri tanpa melupakan orang-orang di sekitarnya untuk maju dan berprestasi bersama. Jadi yang disasar dalam pendampingan ini adalah terkait masalah :

1. Kepemimpinan dan teamwork

2. Konsep diri dan analisis SWOT diri

3. Pengenalan kewirausahaan

\section{METODE PENDAMPINGAN}

Metode pelaksanaan dari kegiatan pendampingan melalui outbond dan pelatihan materi konsep diri, leadership \& teamwork bagi pelajar SMA/SMK/MA penerima beasiswa BAZNAS Daerah Istimewa Yogyakarta tahun anggaran 2019 terdiri dari beberapa tahapan kegiatan. Rangkaian kegiatan diawali dengan melakukan pertemuan antara tim pengabdi dengan perwakilan pimpinan BAZNAS DIY di bulan Februari 2019. Dalam pertemuan ini diinisiasi dari salah satu kegiatan tahunan BAZNAS DIY yang memberikan beasiswa pendidikan bagi para pelajar SMA/SMK/MA. Selanjutnya BAZNAS DIY berharap tidak hanya berhenti pada pemberian beasiswa yang sifatnya finansial, namun juga memberikan nilai lebih pada sisi pengetahuan, psikis atau mental bagi para pelajar tersebut. Maka ditentukanlah waktu, tempat dan materi pendampingan.

1) Materi Pertama adalah tentang kepemimpinan dan teamwork disampaikan dengan model 
pelatihan outbond. Merupakan pelatihan di alam terbuka dengan mensimulasikan materi kepemimpinan dan teamwork melalui permainan-permainan yang secara langsung bisa dipraktikkan peserta pendampingan dengan berpikir terbuka dan kreatif tanpa meninggalkan substansi materi yang ingin disampaikan.

2) Materi kedua adalah tentang konsep diri dan analisis SWOT diri. Materi ini disampaikan secara klasikal dengan pemateri dari beberapa dosen relawan dibantu oleh para mahasiswa untuk membantu mengarahkan peserta dalam kelompok kecil. Materi ini juga dimasukkan dari beberapa aspek baik dari sisi Agama Islam dan teori konvensional. Karena pada dasarnya Islam sebagai rahmatan lil 'alamin bersifat universal dan dapat diterapkan dalam segala lini kehidupan.

3) Materi ketiga tentang kewirausahaan. Materi ini disampaikan secara umum untuk mengenalkan pelajar tentang wacana berwirwausaha didukung dengan cara penghitungan finansial sederhana dan komponenkomponennya. Materi diakhiri dengan FGD atau forum group discussion dengan beberapa kelompok yang terdiri dari 5 pelajar. Kemudian dilanjutkan dengan presentasi perwakilan kelompok.

\section{HASIL KEGIATAN}

Berikut adalah rincian kegiatan pendampingan yang dilakukan oleh tim inti dan para relawan bekerja sama dengan BAZNAS DIY, sebagai berikut:

\begin{tabular}{|c|c|c|c|c|c|c|c|}
\hline \multirow[t]{2}{*}{ No } & \multirow[t]{2}{*}{ Uraian Kegiatan } & \multicolumn{6}{|c|}{ Bulan ke- di tahun 2019} \\
\hline & & 1 & 2 & 3 & 4 & 5 & 6 \\
\hline 1 & Pertemuan/workshop bersama BAZNAS DIY & & & & & & \\
\hline 2 & $\begin{array}{l}\text { Pendampingan 1: Outbond tentang Kepemimpinan dan } \\
\text { teamwork }\end{array}$ & & & & & & \\
\hline 3 & $\begin{array}{l}\text { Pendampingan 2: pelatihan tentang konsep diri dan } \\
\text { analisis SWOT diri }\end{array}$ & & & & & & \\
\hline 3 & $\begin{array}{l}\text { Pendampingan 3: pelatihan tentang pengenalan } \\
\text { berwirausaha dan analisis SWOT usaha berdasar } \\
\text { kearifan lokal }\end{array}$ & & & & & & \\
\hline 6 & $\begin{array}{l}\text { Pertemuan/ Workshop laporan akhir dengan Baznas } \\
\text { DIY }\end{array}$ & & & & & & \\
\hline
\end{tabular}


Pengabdian yang telah dilaksanakan adalah pertemuan awal bagi penerima beasiswa pada hari Sabtu, 23 Februari 2019 di Masjid Gede Kauman pukul 8.00 hingga 12.30. Dikarenakan banyak nya peserta yang harus dihimpun, maka tim pengabdian ini mengundang para relawan yang terdiri dari dosen, mahasiswa dan alumni untuk turut serta mendampingi peserta. Peserta yang awalnya berjumlah 105 karena berbagai faktor hadir 86 peserta kemudian dibagi menjadi kelompok kecil dan dibimbing oleh sebanyak 10 fasilitator (dosen dan mahasiswa) terkait materi kepemimpinan, teamwork yang selain melalui ceramah, diskusi juga melalui outbond. Untuk materi berikutnya dilakukan pada Sabtu, 27 April 2019 di Masjid Gede Kauman pada waktu 8.00 12.00 diakhiri dengan sholat dhuhur di masjid tersebut. Peserta yang hadir adalah sebanyak 98 peserta. Materi disampaikan secara klasikal kemudian masing-masing peserta diminta untuk membuat analisis SWOT diri secara mandiri dengan merujuk pada kondisi pribadi masing-masing peserta. Materi diakhiri dengan presentasi beberapa perwakilan peserta untuk menjelaskan tentang diri sendiri dengan mengelompokkan strength (kekuatan) dan weakness (kekurangan) sebagai komponen internal, serta melihat lingkungan sekitar yang berpotensi opportunity (peluang) dan threat (hambatan) serta mencoba membuat strategi atau langkah-langkah tentang bagaimana melejitkan potensi diri dan meminimalisir kekurangan pada dirinya. Untuk materi ketiga terkait kewirausahaan juga disampaikan secara klasikal untuk mengenalkan pelajar tentang wacana berwirwausaha didukung dengan cara penghitungan finansial sederhana dan komponen-komponennya. Materi diakhiri dengan FGD atau forum group discussion dengan beberapa kelompok yang terdiri dari 5 pelajar. Kemudian dilanjutkan dengan presentasi perwakilan kelompok.

\section{KESIMPULAN}

Di setiap akhir pertemuan atau akhir materi yang disampaikan sebelum waktu dhuhur diberikan kuesioner tentang persepsi para pelajar penerima beasiswa BAZNAS DIY 2019 dengan materi pendampingan yang telah dilakukan. meski tidak dilakukan tabulasi secara empiris, sebagian besar pelajar merasa senang dengan kegiatan yang dilakukan terutama pada materi pertama dengan metode outbond, peserta tidak merasa jenuh, merasa tertantang dan bisa merasakan kolaborasi dengan peserta lain. Sedangkan di materi kedua umumnya peserta masih merasakan kesulitan untuk mengenal potensi diri dengan analisis SWOT. Namun peserta merasa bersemangat dan tercerahkan untuk mau lebih mengenal diri 
sendiri secara lebih terstruktur, sehingga ke depannya dapat menghasilkan langkahlangkah ke depan yang lebih tersistematis dalam mencapai cita-cita masing-masing peserta. Untuk materi ketiga berdasarkan pantauan masing-masing mahasiswa pembimbing bahwa peserta masih kesulitan untuk beradaptasi dengan teman-temang baru di kelompoknya yang berasal dari sekolah dan daerah yang berbeda-beda meski masih satu provinsi Daerah Istimewa Yogyakarta. Masing-masing kelompok beranggotakan dari Kabupaten Sleman, Gunung Kidul, Bantul, Kulonprogo dan Yogyakarta dengan latar belakang potensi kedaerahan yang berbeda. Yang menjadi menarik di sini adalah lebih disadarkan bahwa potensi yang dimiliki berbeda-beda yang sebenarnya sudah diketahui sejak dulu, namun di kelompok "dipaksa" untuk berpikir dan melihat potensi yang ada dan di akhir sesi perwakilan kelompok (terdapat 17 kelompok total 86 peserta) melakukan presentasi secara bersama-sama. Peserta masing-masing materi yang disampaikan memiliki tantangan yang menyenangkan dengan tingkatan yang berbeda-beda.

Kegiatan Pendampingan melalui Outbond dan Pelatihan Materi Konsep diri, Leadership \& Kewirausahaan bagi Pelajar SMA/SMK/MA Penerima Beasiswa BAZNAS Daerah Istimewa Yogyakarta Tahun Anggaran 2019. Diinisiai oleh tim pengabdi yang terdiri dari Andriyastuti Suratman sebagai ketua tim dan anggota Majang Palupi sebagai tenaga pengajar di Program Studi S1 Manajemen Fakultas Ekonomi Universitas Islam Indonesia dan satu mahasiswa anggota yaitu Fadhilla Ibnu Ahzam. Kelompok pengabdi ini mendapatkan dana hibah pengabdian masyarakat dari Direktorat Penelitian \& Pengabdian Masyarakat (DPPM) Universitas Islam Indonesia. Dana dipergunakan untuk seluruh kegiatan pengabdian termasuk untuk pembuatan laporan dan paper publikasi sebagai syarat luaran program ini.

\section{DAFTAR PUSTAKA}

Anoraga, Pandji dan Sudantoko, Djoko. (2002). Koperasi, Kewirausahaan Dan Usaha Kecil. Jakarta: Rineka Cipta.

Mokoginta, Urip. (2001). Pengembangan Kualitas SDM Dari Perspektif PIO. Depok; Bagian PIO Fakultas Psikologi Universitas Indonesia.

Mutammimah. 2014. Hubungan Konsep Diri Dan Kecerdasan Emosi Dengan Kemampuan Penyesuaian Diri Pada Remaja. Persona, Jurnal Psikologi Indonesia Januari 2014, Vol. 3, No. 01, hal $42-51$.

QS Adz Dzariyat : 20-21

QS Ar Ra'du : 11

Rakhmat, Jalaluddin. (2007). Psikologi Komunikasi. Penerbit PT Remaja Rosdakarya, Bandung. hal. 99-100, cetakan ke 24. 
Suryabrata, Sumadi. (2006). Psikologi Kepribadian. Rajawali Pers.

Suryana. (2013). Kewirausahaan:kiat dan proses menuju sukses. Jakarta: Salemba Empat.

Uno, Hamzah B. (2011). Teori Motivasi dan Pengukurannya Alalisis di Bidang Pendidikan. Jakarta : Bumi Aksara 